\title{
SOCIAL AND ECONOMIC AVAILABILITY OF FOOD FOR THE POPULATION OF THE REGION: METHODICAL ASPECT
}

\author{
Tatyana M. Yarkova \\ Doctor of Economics, Professor, Perm State Agrarian and Technological University named after the \\ academician D.N. Pryanishnikov \\ Address: 614990, Perm, Petropavlovskaya
}

\begin{abstract}
The article assesses the importance of food security in modern conditions. The direct affiliation and the relationship of food security with the society and the economic development of the territories were noted. They presented the author's position on food security and food availability monitoring according to the level of incomes and expenditures of the country population. The proposed methodology was tested on the basis of the available known data of Rosstat. Thus, they determined the level of socioeconomic accessibility of the Russian population in eight main types of food.
\end{abstract}

Keywords: population, region, methodical aspect

\section{INTRODUCTION}

The socio-economic development of a state depends on many factors of internal and external environment. In this regard, it will be true that the main criterion reflecting the degree of society social and economic development in a particular state or a territory (region) is the level of food security. The strategic nature of the solution is inherent in this problem of food security, because this problem is exacerbated increasingly by the expansion of economic sanctions of the West. The accelerated development and the modernization of the agro-industrial complex, the development of competitive agricultural and food production, the stabilization of the domestic food market, the development of independence from imports and an efficient logistics, as well as the improvement of population life level and quality in various regions of Russia should be included in the tasks to solve the abovementioned problem [5].

The solution of these tasks will contribute to the achievement of food security goals. By the way, it is important to note that many scientists see the goals of food security completely differently and at different periods of time, which they state in the interpretation of "food security" concept. Let's consider some of them.

According to V. Rudash and V. Dadalko, "food security" is the level of food availability for the main part of the country population to maintain a necessary and a sufficient lifestyle. At the same time, the well-known fact is that food security makes an important component of a state national and economic security system. And in this regard, one of the fundamental interpretations of "food security" is its interpretation as the ability of the agricultural sector of the economy to provide food industry with agricultural raw materials, and to provide population with necessary food [6;3].

Indeed, in modern conditions - the conditions of sanctions imposed on Russia by the EU and the US, and an unstable economic and political situation, the provision of food security is one of the topical and priority trends in the development of our country economy [12]. That is, food security is mostly oriented towards the state of regional or state economy, on which the physical availability of food depends, of course.

However, many works of well-known scientists, make a significant emphasis on the social importance of food security. For example, N. Zhakhov notes in his works that "food security" is one of the necessary guarantees of the human right to life [4]. Therefore, it is impossible to consider the problem

Submit Date: 10.01.2018, Acceptance Date: 23.02.2018, DOI NO: 10.7456/1080MSE/126

Research Article - This article was checked by Turnitin

Copyright (C The Turkish Online Journal of Design, Art and Communication 
of food security only from the physical (economic) accessibility of food for population, it is necessary to include the parameters of social accessibility in the known system of assessment, which should also be linked to the economic development of our society [11]. In this regard, the following opinion of such researchers as P. Zhuravlev and A. Konobeeva will be reasonable: the food security is not only the guarantor of the economic security of the country, but also of its statehood and sovereignty preservation, as well as an important condition of demographic policy and national strategy development to improve the quality of country citizen life [5].

This approach allows one to assume that food security has a profoundly significant social effect due to the fact that it is oriented towards the citizens of the country and their life quality.

Another proof of the socio-economic aspect of food security is the study entitled "The right to adequate food and freedom from hunger", which was prepared by the Commission on Human Rights of UN Economic and Social Council, where "food security" is interpreted as the access of all people to food, necessary for a healthy and active life at any time [7,9]. And this is the correct point of view, indeed, which is certainly primary one in connection with the known truths prescribed by the classic representative of management - the American psychologist A. Maslow - these are physiological (organic) needs (food, water, etc.).

However, the sociological significance of food security and the process of food supply do not end here. It has practically unlimited meaning, which will be actively traced in the scientific research of domestic and foreign scientists $[1,2]$.

It is quite a fair assertion that the economic accessibility of food is represented as the level of food consumption, depending on the ratio of income per capita and the subsistence minimum [7]. In fact, this approach allows us to take into account the social aspect of the issue and is methodical one for the state of food security evaluation according to certain criteria.

In contrast to this approach, I. Trorova [8] believes that it is necessary to use three main indicators for the purposes of the total quantitative comparison of economic accessibility level - the poverty rate; the coefficient of population purchasing power and the coefficient of income concentration by Ginny index. It is important to pay attention to the fact that both methodical trends have one basis - the population incomes. At the same time, this indicator fully reflects not only the economic, but also the social aspect of the issue. In this regard, it will be most appropriate to use the term "social and economic accessibility of food" in relation to this indicator. Using such a dual system approach to assess food security, it is possible to obtain qualitative information about the state of affairs either in society or in the economy of the agroindustrial complex and its branches, as well as in other spheres of the economy, in order to identify problems and their further point-by-point solution.

\section{METHODOLOGY}

So, taking into account the purpose of the scientific research included in the title of this scientific article, we would like to note that the research will be based on selected types of food from the basic ones, and the necessary data for the Russian Federation officially provided by the Federal State Statistics Service.

However, this study will rely only on the socio-economic accessibility of basic food due to its limited nature.

The basis for this indicator should include two main criteria 10]:

1) actual expenditures of the population on basic types of food per year $\left(F_{f}\right)$;

$F_{f}=\sum_{i=1}^{n} \frac{Y_{i} \times \bar{D} \times H}{100} \times 12$

where $Y_{i}$ are the expenditures of region households for the i-th type of basic food, \%;

$\bar{D}-$ per capita incomes of the population per month, rubles;

$\mathrm{H}-$ the population amount in a region, men;

Submit Date: 10.01.2018, Acceptance Date: 23.02.2018, DOI NO: 10.7456/1080MSE/126

Research Article - This article was checked by Turnitin 
100 - constant conversion factor $\%$ in natural values;

12 - the number of months in a year.

- normative expenditures of the population for basic types of food, rubles $\left(\mathrm{R}_{\mathrm{N}}\right)$.

$R_{N}=\sum_{i=1}^{n}\left[C_{i} \times \sum_{j=1}^{n}\left(N_{i} \times K_{h i} \times h_{j}\right)\right]$,

where $C_{i}$ is the price for the i-th type of main food, rub./kg.

Thus, we obtain the author's formula [10], which allows us to determine the degree of basic food socioeconomic accessibility (W):

$\mathrm{W}=F_{f} / R_{N} \rightarrow 1$,

in the expanded form which looks as follows:

$\mathrm{W}=\sum_{i=1}^{n} \frac{Y_{i} \times \bar{D} \times H}{100} \times 12 / \sum_{i=1}^{n}\left[C_{i} \times \sum_{j=1}^{n}\left(N_{i} \times K_{h i} \times h_{j}\right)\right] \rightarrow 1$,

According to the presented formulas 3 and 4 , it is possible to determine the level of social and economic accessibility to the population of a country or a region, while their effective value should tend to unity. If a desired indicator is equal to one, in this case we can talk about the provision of an adequate nutrition, which contributes to the preservation of a healthy lifestyle, and can exclude the overexpenditure of the population funds on food. Along with this, it is necessary to present the threshold values developed by the author (Table 1), characterizing the actual state in the sphere of socio-economic accessibility of food to the population of a region (a country).

Table 1 - The matrix of criticality zones for socio-economic access to food *

\begin{tabular}{|c|c|c|}
\hline k zone & $\begin{array}{l}\text { e degree of socio- } \\
\text { nomic } \\
\text { essibility of food } \\
\text { ic types of food } \\
\text { ), the share of un. }\end{array}$ & $\begin{array}{l}\text { aracteristics of food security level, incl. food } \\
\text { nagement activities. }\end{array}$ \\
\hline k-free zone & $\begin{array}{rr}-1 & \text { and more } \\
\text { n } 1 & \end{array}$ & $\begin{array}{l}\text { ble functioning of food markets, the possibility of } \\
\text { icultural product export outside a region (a country) } \\
\text { reases. }\end{array}$ \\
\hline $\begin{array}{ll}\text { missible risk } \\
\text { he }\end{array}$ & $-0,89$ & $\begin{array}{l}\text { lable functioning of food markets, there is a need to } \\
\text { m food stocks to provide socially important facilities } \\
\text { l low-income segments of population. }\end{array}$ \\
\hline tical risk zone & $1-0,79$ & $\begin{array}{l}\text { sustainable food security, characterized by the growth } \\
\text { imported food on the market, the quality of food, the } \\
\text { mber of undernourished is growing due to the large } \\
\text { mber of poor people. Stable reserves should be } 50 \% \text { at } \\
\text { st. Export is excluded. }\end{array}$ \\
\hline $\begin{array}{ll}\text { tastrophic risk } \\
\text { he }\end{array}$ & ss than 0,5 & $\begin{array}{l}1 \text { dependence on imports, more than } 50 \% \text { of the } \\
\text { bulation is starving, the growth of unprofitability and }\end{array}$ \\
\hline
\end{tabular}

Submit Date: 10.01.2018, Acceptance Date: 23.02.2018, DOI NO: 10.7456/1080MSE/126

Research Article - This article was checked by Turnitin

Copyright (C) The Turkish Online Journal of Design, Art and Communication 


\begin{tabular}{|l|l|}
\hline & $\begin{array}{l}\text { liquidation of agricultural enterprises. The distribution } \\
\text { food supplies for food needs of all socially important } \\
\text { ilities and the needy population by organizing the } \\
\text { ivery of food via food cards. }\end{array}$ \\
\hline
\end{tabular}

* The table was drawn up on the basis of the author's studies

\section{STUDY RESULTS}

The next important step in the presented study is the approbation of the technique developed by the author, i.e. the monitoring of current food security in Russia, where the key criterion will be the calculation of the socio-economic accessibility of food to the population of the country.

The basis of this indicator calculation by the author are the values of the used population resources (incomes) for all main types of foodstuffs analyzed, their fixed prices, the consumption rates, taking into account the age and the sex composition of RF population.

It is important to note that it is reasonable to calculate the level of socio-economic accessibility for each type of basic food consumed by the population of the country.

The consolidated figures, obtained as the result of laborious calculations, were placed in Table 2.

Table 2 - The calculation of socio-economic accessibility ratio of the main types of food consumed by Russian Federation population in 2015

\begin{tabular}{|c|c|c|c|c|c|c|c|c|}
\hline $\operatorname{lin}_{\mathrm{d}}$ types of & 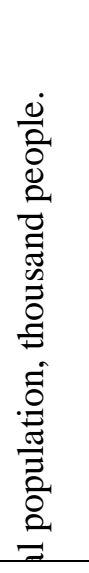 & 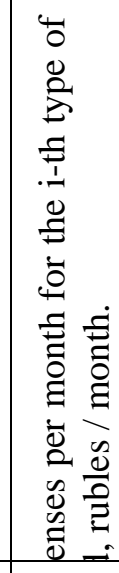 & 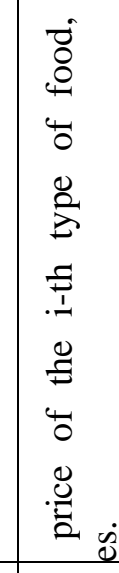 & 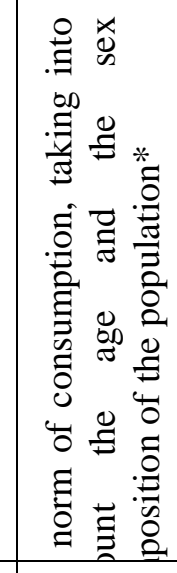 & 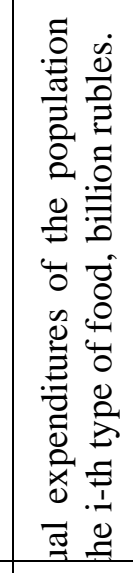 & 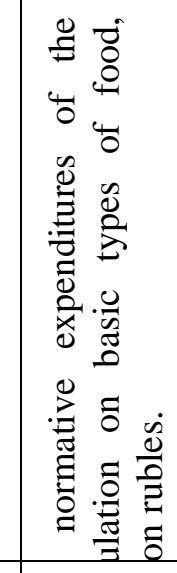 & 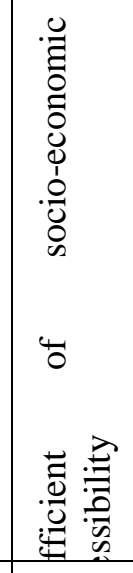 & 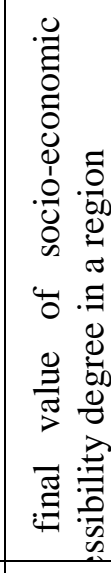 \\
\hline $\begin{array}{l}\mathrm{lk} \text { and milk } \\
\text { ducts }\end{array}$ & \multirow[b]{8}{*}{6} & 4,07 & 78 & 99 & 0,85 & 71,74 & 5 & \multirow{8}{*}{6} \\
\hline $\begin{array}{l}\text { at and meat } \\
\text { ducts }\end{array}$ & & 2,96 & 0,2 & 4 & 31,18 & 52,09 & 3 & \\
\hline $\begin{array}{l}\text { ead and bakery } \\
\text { pducts }\end{array}$ & & 1,85 & 61 & 11 & 4,91 & 5,35 & 8 & \\
\hline getables & & 78 & 38 & 82 & 4,07 & 3,58 & 1 & \\
\hline fatoes & & 7,04 & 91 & 59 & 5,42 & 9,41 & 8 & \\
\hline $\begin{array}{l}\text { getable oil and } \\
\text { er vegetable } \\
\end{array}$ & & 15 & 7,6 & 7 & 8,39 & 5,75 & 5 & \\
\hline gar & & 0,93 & 14 & 6 & 2,46 & 3,28 & 4 & \\
\hline gs & & 78 & 0 & 52 & 4,07 & 7,66 & 7 & \\
\hline
\end{tabular}


* bread and bakery products (in terms of flour consumption); meat and meat products; milk and milk products; vegetables; potatoes; vegetable oil and other vegetable fats; sugar - thousand tons; egg million pieces.

\section{Figure 1 clearly reflects the state of socio-economic accessibility of food products (among basic ones) for RF population in 2015.}

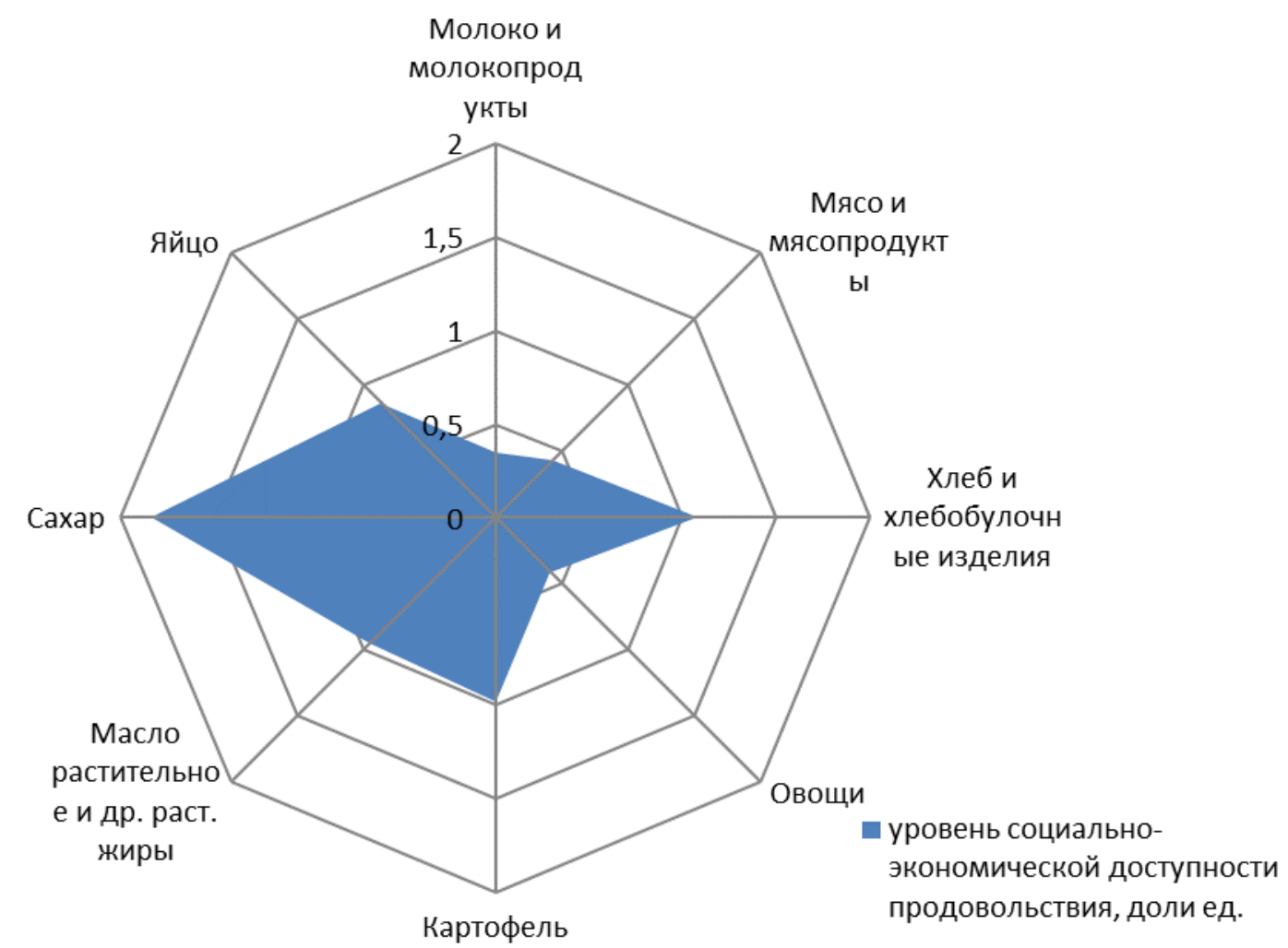

Молоко и молокопродукты - Milk and milk products / Яйцо - Eggs / Мясо и мясопродукты - Meat and meat products / Cахар - Sugar / Хлеб и хлебобулочные изделия - Bread and bakery products / Масло растительное и другие растительные жиры - Vegetable oil and other vegetable fats / Картофель - Potatoes / Овощи - Vegetables / уровень социально-экономической доступности продовольствия, доли ед. - the level of socio-economic accessibility of food products, share of un.

Figure 1. The level of socio-economic accessibility for basic types of food in Russian Federation during 2015 , share of un.

Figure 1 allows you to talk about the following characteristic features of socio-economic accessibility of food for the population:

1) the most accessible type of food is sugar, its level of availability was 1.84 of unit fraction, i.e. it is $84 \%$ higher than the required level of consumption;

2) there are such types of food as bread and bakery products, potatoes, vegetable oil and eggs at the level equal to or close to one. Their level makes $1.08 ; 0.98 ; 0.95$ and 0.87 respectively;

3 ) such products as milk and dairy products, as well as meat and meat products and vegetables are in the zone of catastrophic risk as the result of evaluation. 


\section{CONCLUSIONS}

Concerning the socio-economic accessibility, there are problem areas conditioned by low incomes and high prices for certain types of food. However, this is only a superficial vision of the obtained result. It should be noted that such an assessment must be accompanied necessarily by the calculation of competitiveness and production efficiency level in a region or a country for all food types being examined.

In this regard, according to the author's own study, it can be argued that, the production of such types of food as milk, meat and vegetables in the country are under a special program-target regulation indeed, because they have rather unstable efficiency in all regions where their production is possible. In the same regard, a very unfavorable role was fulfilled and consolidated by the import of these types of foodstuffs, with which Russian Federation is struggling currently, taking the policy of import substitution during the period of 2000-2010. And the last thing you need to focus on is the current type of food in Russia, which is mostly represented by a carbohydrate and a high-calorie type. This type of food has been assigned to most of Russia due to certain natural and climatic conditions and a sufficiently long period of low living standards, which does not allow to spend more money on other types of food.

It is important to note that the limited amount of available resources leads to the demand of low quality and grade import at food markets. This kind of situation is still typical for modern conditions, especially when the volumes and the quality of food products consumed are wholly dependent on cash and natural income for the population.

So, the conducted monitoring, based on the calculation of socio-economic accessibility indicators, showed that the country food markets are characterized by a high level of supply for most of the main types of food in general. However, for individual types of food, the results of its production and sale can not be called positive, but rather more negative. This situation is explained by two particularly important factors: low level of food production as the result of the agrarian sector weak development, as well as population low income, which determines the decrease of demand due to a high price, which contributes to imported goods capacity increase for the domestic market.

\section{REFERENCES}

Gogolev I.M. AIC of the region for the population provision with food products [Text] / I.M. Gogolev, D.A. Lyubimov, M.V. Gogolev // The Problems of Regional Economics. - 2010. № 3-4. - pp. 183-192

Dugina E.L. The formation and the development of the food market in Russia [Text] / E.L. Dugina, E.V. Dorzhieva. Ulan-Ude: The Publishing House of VS State Technical University, 2009. - p. 63

Dadalko V.A. Food security as the component of national and economic security // UGATU Bulletin. 2013. - No. 7 (60). - pp. 17-25.

Zhakhov N.V. The development of agriculture and food security in Russia // Scientific support of the agro-industrial complex: the collection of articles on the materials of the IXth All-Russian Conference for Young Scientists (editor in charge: A.G. Koshchaev). 2016. pp. 1017-1018

Zhuravlev P.V., Konobeeva A.B. Food security - the indicator of economic development of Russia level // Bulletin of the Academy. 2016. № 1. pp. 5-10.

Rudash Zh.V. State policy of food security provision in Russia // Economics and management: the analysis of trends and the prospects for development. 2016. No. 25. pp. 81-87

Simonova S.S. The social function of the state to ensure food security // Business. Education. Law. 2014. No. 2 (27). pp. 275-277

Totrova I.K. The evaluation of food availability level for the population of North Ossetia-Alania [Text] / I.K. Totrova // Proceedings of the Gorsky State Agrarian University. 2010. V. 47. № 2. pp. 173-176 Chernova O.A., Stepenko V.E. "Food security": scientific and theoretical approaches to the definition of terminology // The legal world. 2006. № 10 (118). pp. 51-56

Yarkova T.M. Economic technologies of regional food stock development and use in the conditions of the WTO: dis. by the Doct. of economics: 08.00.05 [Text] / Yarkova Tatyana Mikhailovna. Ekaterinburg, 2014. - 405 p.

Submit Date: 10.01.2018, Acceptance Date: 23.02.2018, DOI NO: 10.7456/1080MSE/126

Research Article - This article was checked by Turnitin 
Reform of the Common Agricultural Policy: a long-term perspective for sustainable agriculture (impact analysis) [Electronic resource] / Commission of the European community's // Proposal for a council regulation establishing common rules for direct support schemes under the common agricultural policy and support schemes for producers of certain crops. - Brussels, 21.1.2003. - Access mode: http://www.ecologic-events.de/cap2003/en/documents/EC_midterm_03.pdf

Markusen A. Regions: economics and politics of territory [Text] / A. Markusen. - Rowman \& Littlfield publishers, 1987 